\title{
HPV education and vaccination in a public hospital in Brazil
}

Candice Amorim de Araujo Lima SANTOS ${ }^{1}$, Jurema Telles de Oliveira LIMA1', Vedner GUERRIER²,Carla Rameri Alexandre Silva de AZEVEDO', Maria Júlia Gonçalves de MELLO'

(1) Instituto de Medicina Integral professor Fernando Figueira/ IMIP-PE/ Brasil.

(2) Oncology Service at Memorial Healthcare System, Hollywood Florida, USA.

ASCO Quality

Training Program
Instituto de

Medicina

Integral

Prof. Fernando

Figueira

\section{Objective:}

Official statistics reports a low HPV vaccination rate in Brazilian teenagers. Education about HPV vaccination is considered an area for improvement and our aim was increase the number of patients educated about the importance of HPV vaccination thus improving the HPV vaccination rate.

\section{Methods:}

Between September 2018 and December 2018, in the Oncology Department at IMIP, we undertook a structured approach to educate the female cancer patient about HPV and its relationship with cervical cancer with support from ASCO's Quality Training Program. Our team used standard plan-do-study-act (PDSA) methodology to achieve our goal of increase by $50 \%$ the number of patients educated about the importance of HPV vaccination. We also analyzed rate of HPV vaccination at our institution before and after this intervention.

\section{Results:}

Before October 2018 a mean of 1263 female cancer patients were consulted at IMIP per month and none were educated about HPV vaccination. After our PDSA we had a mean of 1087 female cancer patients consulted per month, and we educated about $16 \%$ of them. We had no improvement in the HPV vaccination rate. Before October 2018 there was a mean of 39 teenagers vaccinated per month, an after, a mean of 20.

\begin{tabular}{|llll|}
\hline $\begin{array}{c}\text { Date of PDSA } \\
\text { Cycle }\end{array}$ & \multicolumn{1}{c|}{$\begin{array}{c}\text { Description of } \\
\text { Intervention }\end{array}$} & \multicolumn{1}{c|}{ Results } & \multicolumn{1}{c|}{ Action Steps } \\
\hline October 2018 & $\begin{array}{l}\text { Change in the } \\
\text { consultations process } \\
\text { to include HPV } \\
\text { education during } \\
\text { new patient visit }\end{array}$ & $\begin{array}{l}\text { Change in physician } \\
\text { and staff workflow } \\
\text { and offers patient the } \\
\text { education which was } \\
\text { missing prior }\end{array}$ & $\begin{array}{l}\text { Changed workflow- } \\
\text { Monitoring impact of } \\
\text { education on IMIP } \\
\text { vaccination rates }\end{array}$ \\
\hline October 2018 & $\begin{array}{l}\text { Development of } \\
\text { educational material } \\
\text { and video infomercial } \\
\text { about HVP } \\
\text { vaccination in the } \\
\text { waiting areas }\end{array}$ & $\begin{array}{l}\text { Some patient not } \\
\text { happy about seeing } \\
\text { the videos multiple } \\
\text { times and wanted to } \\
\text { watch other TV } \\
\text { shows. }\end{array}$ & $\begin{array}{l}\text { Staff member } \\
\text { decided to directly } \\
\text { educate patients in } \\
\text { the waiting room }\end{array}$ \\
\hline October 2018 & $\begin{array}{l}\text { Development of } \\
\text { questionnaire for } \\
\text { vaccination and } \\
\text { tracking log by staff } \\
\text { performing the } \\
\text { injections }\end{array}$ & $\begin{array}{l}\text { Not consistently } \\
\text { documenting the } \\
\text { patient injection } \\
\text { process }\end{array}$ & $\begin{array}{l}\text { Re-educate staff on } \\
\text { log utilization and } \\
\text { documentation }\end{array}$ \\
& & & \\
\hline
\end{tabular}
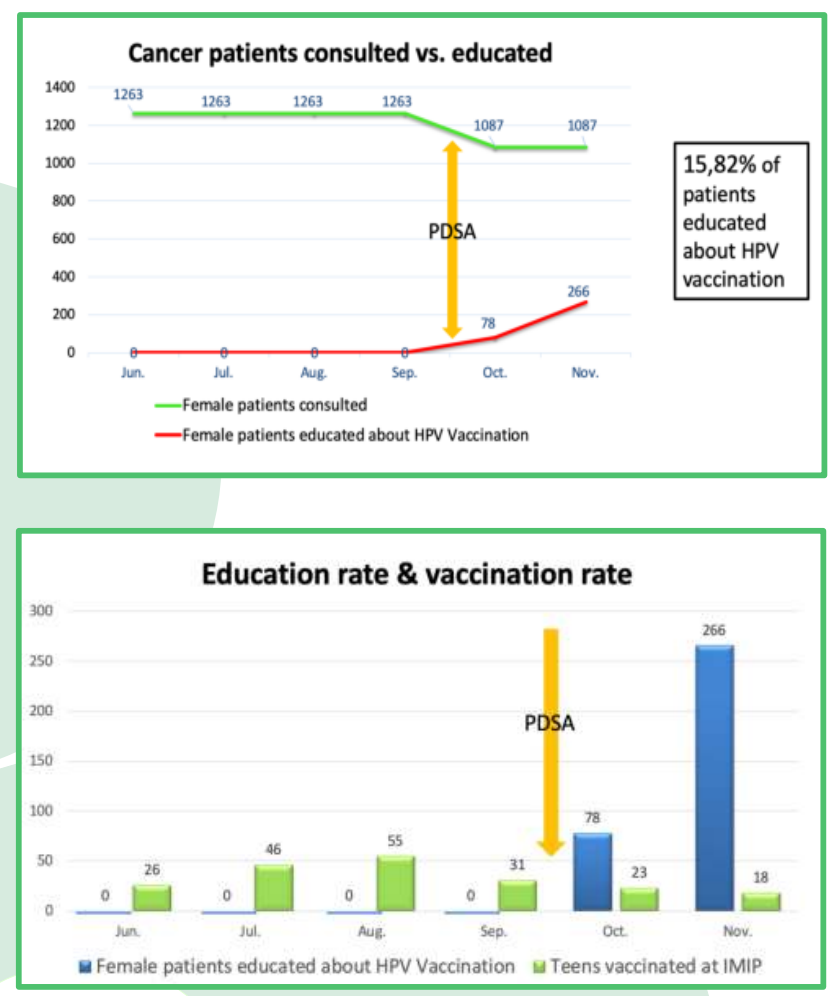

\section{Conclusions:}

After one cycle of PDSA, we have increased our patient education, however there was no improvement in the vaccination rate at IMIP. Maybe, as IMIP is a tertiary center, we could not observe such changes, but primary health services rates of vaccination may reflect better the impact of this intervention. We still believe education as a tool against cervical cancer.

References

1. Ministério da Saúde (BR). Instituto Nacional de Câncer José Alencar Gomes da Silva. Estimativa Câncer 2018: incidência de câncer no Brasil. Rio de Janeiro (RJ):INCA, 2018.

2.http://pni.datasus.gov.br/consulta hpv 14 selecao.php 3. https://portalarauivos2 saude. aov.br/images/odf/2018/marco/13/Campanha-HPV2018.pdf 